\title{
MODEL PEMBELAJARAN PROBLEM BASED LEARNING DAPAT MENINGKATKAN HASIL BELAJAR SUBTEMA KEBERAGAMAN BUDAYA BANGSAKU
}

\author{
Obaja Dwi Handoko ${ }^{1}$, Henny Dewi ${ }^{2}$, Sri Giarti ${ }^{3}$ \\ 1,2,3 Jurusan Pendidikan Guru Sekolah Dasar, FKIP \\ Universitas Kristen Satya Wacana \\ Salatiga, Indonesia \\ email : 292014121@student.uksw.edu', dewi@staff.uksw.edu², \\ sgiarty@gmail.com ${ }^{3}$
}

\begin{abstract}
Abstrak
Penelitian ini merupakan penelitian tindakan kelas yang bertujuan untuk mendeskripsikan langkah-langkah penggunaan model pembelajaran Problem Based Learning dalam meningkatkan hasil belajar Subtema Keberagaman Budaya Bangsaku. Penelitian dilaksanakan di SD Negeri Purwosari 01 Kabupaten Temanggung dengan subjek penelitian adalah siswa kelas IV SD Negeri Purwosari 01. Variabel bebas dalam penelitian ini adalah model pembelajaran Problem Based Learning, sedangkan variabel terikatnya,yaitu hasil belajar siswa. Pengumpulan data dilakukan dengan cara observasi dan tes. Penelitian dirancang untuk dilaksanakan dalam dua siklus. Setiap siklus terdiri atas empat tahap, yaitu tahap perencanaan, tahap tindakan, tahap pengamatan, dan tahap analisis dan refleksi. Teknik analisa data dalam penelitian ini terbagi menjadi dua, yaitu analisa data kuantitatif, berupa angka hasil belajar siswa, dan data kualitatif, berupa kalimat yang menggambarkan hasil pengamatan observer terhadap pembelajaran yang dilaksanakan. Hasil penelitian menunjukkan bahwa model pembelajaran Problem Based Learning dapat meningkatkan hasil belajar siswa. Analisis data hasil belajar menunjukkan pada prasiklus ketuntasan belajar siswa hanya $23,08 \%$, meningkat menjadi $46,15 \%$ pada siklus I dan pada siklus II ketuntasan belajar sudah tercapai sebesar $92,31 \%$
\end{abstract}

Kata Kunci : Problem Based Learning, Hasil Belajar

\begin{abstract}
This study has a purpose to describe the steps of using Problem Based Learning model, in improving learning outcomes Subtheme Curtural Diversity in My Country. The research was conducted in SD Negeri Purwosari 01 Temanggung Regency with the subject of research is the fourth grader of SD Negeri Purwosari 01. The independent variable in this research is the learning model of Problem Based Learning, while the dependent variable, that is student learning outcomes. Data collection by observation and test. this study is designed to be implemented in two cycles. This study is designed to be implemented in two cycles. Each cycle consists of four stages: planning, action, observation, and analysis and reflection. Data analysis techniques in this study are divided into two, the first is the analysis of quantitative data, is the value of student learning outcomes, and the second is the qualitative data, sentences that describe the results of observations on the implementation of learning. The results showed that the application of Problem Based Learning model can improve student learning outcomes. The analysis of learning result data shows that students' learning completeness is only $23.08 \%$, increased to $46.15 \%$ in cycle I and in cycle II the learning completeness has reached $92.31 \%$.
\end{abstract}

Keyword : Problem Based Learning, Learning Result 


\section{Pendahuluan}

Pendidikan merupakan suatu kebutuhan yang harus di penuhi dalam kehidupan manusia sepanjang hayat. Secara formal Pendidikan itu dilaksanakan sejak usia dini hingga perguruan tinggi (Hajar,2015). Terkusus Pendidikan jenjang Sekolah Dasar adalah pondasi untuk membangun masa depan siswa menjadi lebih baik lagi. Selain itu pendidikan di Sekolah Dasar juga menjadi jenjang awal untuk siswa dapat melanjutkan ke jenjang selanjutnya yang lebih tinggi. Hal tersebut menjadi ambisi tersendiri bagi dunia kependidikan di Indonesia. Saat ini Indonesia telah menggunakan kurikulum baru yaitu kurikulum 2013. (Sagala, : 2011:1) Didalam kurikulum 2013 ini terdapat beberapa langkah yang di harapkan meningkatkan kualiatas Pendidikan di Indonesia. Rusman (2017:254) menyatakan bahwa pembelajaran tematik terpadu memuat beberapa mata pelajaran yang bertujuan untuk memberikan pengalaman bermakna kepada siswa, karena dalam pembelajaran tematik terpadu siswa akan memahami konsep-konsep yang mereka pelajari melalui pengalaman langsung dan menghubungkanya dengan konsep lain yang telah dipahami.

Kendala dalam mempelajari pembelajaran tematik dialami oleh siswa kelas IV SD Negeri 01 Purwosari Kabupaten Temanggung. Terbukti melalui hasil observasi awal yang dilakukan pada siswa kelas IV SD Negeri 01 Purwosari Kabupaten Temanggung menunjukkan bahwa hasil belajar siswa masih rendah Hasil belajar yang dicapai siswa dipengaruhi oleh dua faktor, yaitu faktor intern yang berasal dari siswa tersebut, dan faktor ekstern yang berasal dari luar diri siswa tersebut (Sudjana, 2010). Faktor dari diri siswa terutama adalah kemampuan yang dimilikinya. Faktor kemampuan siswa besar sekali pengaruhnya terhadap hasil belajar yang dicapai siswa, Faktor khususnya pada pembelajaran subtema Keberagaman Budaya Bangsaku. Rendahnya hasil belajar ini ditunjukkan dari nilai ulangan siswa yang sebagian besar masih berada di bawah batas Kriteria Ketuntasan Minimal (KKM), yaitu 70. Karena pencapaian hasil belajar yang masih rendah, maka guru membutuhkan pengulangan atau perbaikan proses pembelajaran agar hasil belajar dapat meningkat minimal sama dengan kriteria ketuntasan minimal. Untuk meningkatkan proses pembelajaran diperlukanya metode pembelajaran, menurut Komalasari (2010: 46) model pembelajaran merupakan bungkus atau bingkai dari penerapan suatu pendekatan, metode, dan teknik pembelajaran. Model pembelajaran merupakan pola yang digunakan sebagai pedoman dalam merencanakan pembelajaran di kelas.

Selama ini, guru dalam mengajarkan subtema Keberagaman Budaya Bangsaku masih banyak menggunakan metode ceramah. Selain itu, guru juga tidak memanfaatkan media untuk mendukung pembelajaran. Karena pembelajaran yang monoton, maka guru tidak bisa mengetahui dan mengukur keterampilan siswa dalam memecahkan masalah. Tidak adanya kesempatan siswa untuk melakukan diskusi, baik secara kelompok maupun klasikal, menyebabkan siswa tidak memiliki keterampilan dalam memecahkan masalah terkait subtema yang diajarkan guru. Hal ini kemudian berdampak pada nilai hasil belajar yang rendah.

Merujuk pada model yang digunakan dalam pembelajaran Kurikulum 2013, maka peneliti memilih model Problem Based Learning (PBL) untuk diterapkan dalam perbaikan pembelajaran tersebut. Model PBL tersebut efektif untuk mengembangkan keterampilan proses, sehingga akan mempengaruhi peningkatan hasil belajar yang lebih signifikan. Problem Based Learning adalah model pembelajaran yang secara langsung memberikan permasalahan untuk di pecahkan, sehingga siswa secara tidak langsung mencari pemecahan masalah yang ada, dan tentu saja keterampilan siswa dalam memproses pembelajaran menjadi semakin aktif.

Di dalam Problem Based Learning, tidak hanya difokuskan pada hasil belajar, tetapi juga pada proses belajarnya sehingga akan meningatkan hasil belajar siswa. Hal itu dibuktikan melalui penelitian yang dilakukan Dede Suryani (2016:2) yang berjudul "Penerapan Problem Based Learning untuk Meningkatkan Pemahaman Hasil Belajar Siswa Kels IV SDN Leuwiliang Sumedang pada Subtema Kebersamaan dalam Keberagaman, 
yang membuktikan bahwa penerapan model Problem Based Learning dalam pembelajaran mampu meningkatkan pemahaman hasil belajar siswa. Diperkuat juga dengan penelitian yang dilakukan oleh Koeswati (2018:116) bahwa model Problem Based Learning dapat meningkatkan Keterampilan Berpikir Kritis dan Hasil Belajar Pada Sub Tema Lingkungan Tempat Tinggalku Kelas 4 SD.

Berdasarkan latar belakang diatas, maka peneliti tergerak untuk melakukan penelitian yang berjudul "Model Problem Based Learning Untuk Meningkatkan Hasil Belajar Siswa Kelas 4 Subtema Keberagaman Budaya Bangsaku di SDN Purwosari 01 Temanggung Tahun Pelajaran 2018/2019".

\section{Metode}

Penelitian yang akan digunakan ini merupakan penelitian tindakan kelas (classroom action research) tidak lain bertujuan untuk meningkatkan hasil belajar dalam pembelajaran subtema Keberagaman Budaya Bangsaku pada siswa kelas IV SD Negeri Purwosari 01 Temanggung, melalui penerapan model pembelajaran Problem Based Learning dalam memproses pembelajaran.

Rancangan penelitian yang digunakan adalah dengan rancangan model penelitian tindakan, berbentuk siklus. Penelitian ini akan dilaksanakan dalam dua siklus, dan langkahlangkah setiap siklus terdiri dari perencanaan, pelaksanaan, observasi, dan refleksi. Gambaran proses penelitian tindakan kelas ini tampak sebagai berikut.

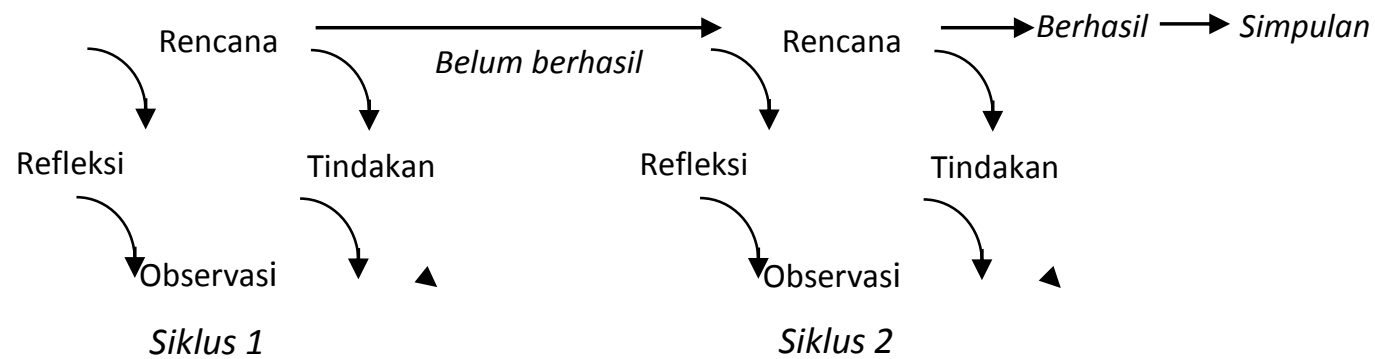

Gambar 1. Proses Penelitian Tindakan Kelas

Berdasarkan siklus di atas, maka dalam satu kelas akan diberikan beberapa kali tindakan. Banyaknya siklus yang dilaksanakan dalam penelitian tindakan kelas ini tidak ditentukan. Data dalam penelitian ini diperoleh melalui hasil observasi dan hasil belajar siswa. Dalam penelitian ini data yang diperlukan antara lain: 1) data hasil dari aktifitas guru dalam menerapkan model Problem Based Learning yang diperoleh dari lembar observasi dalam pelaksanaan model pembelajaran Problem Based Learning; 2) data hasil dari aktifitas siswa dalam menerapkan model Problem Based Learning yang diperoleh dari lembar observasi penggunaan model pembelajaran Problem Based Learning; 3) hasil belajar siswa yang diperoleh melalui tes evaluasi yang diberikan di setiap akhir siklus I dan siklus II selama kegiatan pembelajaran berlangsung.

Kriteria keberhasilan dalam penelitian ini dapat dilihat dari keberhasilan hasil belajar siswa, yang didasarkan pada peningkatan dalam mencapai taraf keberhasilan minimal yang ditentukan, yaitu antara $70 \%$ dari jumlah siswa yang mengikuti proses belajar mengajar telah mencapai KKM sebesar 75

\section{Hasil dan Pembahasan}

Berdasarkan hasil tindakan dapat diketahui bahwa terjadi peningkatan hasil belajar siswa pada Tema Indahnya Kebersamaan di kelas IV SD Negeri Purwosari 01 Kabupaten Temanggung. Perbandingan hasil belajar siswa disajikan pada tabel berikut. 
Tabel 1. Analisis Ketuntasan Hasil Belajar Siswa Pra Siklus, Siklus I dan Siklus II

\begin{tabular}{lcccccc}
\hline \multicolumn{1}{c}{ Keterangan } & \multicolumn{2}{c}{ Pra Siklus } & \multicolumn{2}{c}{ Siklus I } & \multicolumn{2}{c}{ Siklus II } \\
& $\mathrm{f}$ & $\%$ & $\mathrm{f}$ & $\%$ & $\mathrm{f}$ & $\%$ \\
\hline Tuntas & 3 & 23,08 & 6 & 46,15 & 12 & 92,31 \\
Tidak Tuntas & 10 & 76,92 & 7 & 53,85 & 1 & 7,69 \\
Jumlah & 13 & 100 & 13 & 100 & 13 & 100 \\
\hline
\end{tabular}

Berdasarkan tabel di atas dapat dijelaskan bahwa tingkat ketuntasan belajar siswa dari pra siklus sampai ke siklus II mengalami peningkatan. Pada pra siklus siswa yang tuntas belajar adalah 3 siswa (23,08\%), pada siklus I menjadi 6 siswa $(46,15 \%)$, dan pada siklus II menjadi 12 siswa (92,31\%). Sedangkan jumlah siswa yang belum tuntas mengalami menurun. Pada saat pra siklus terdapat 10 siswa (76,92\%) belum tuntas, pada siklus I terdapat 7 siswa $(53,85 \%)$ yang belum tuntas dan pada siklus II hanya 1 siswa $(7,69 \%)$ yang belum tuntas dalam hasil belajarnya. Di dalam memperjelas perbandingan hasil belajar dan ketuntasan belajar siswa dari prasiklus sampai dengan siklus II disajikan dalam gambar berikut.

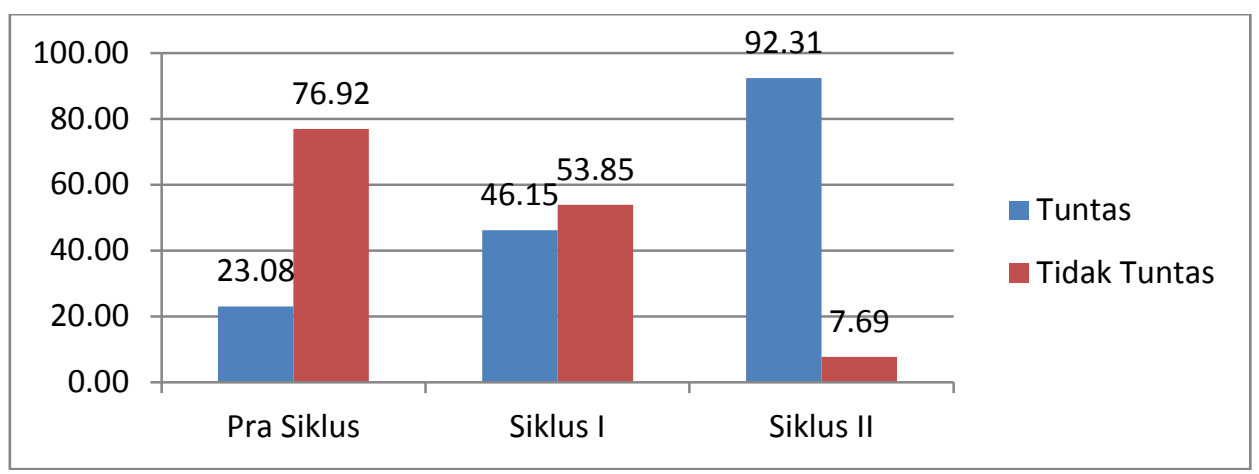

Gambar 2. Distribusi Frekuensi Hasil Belajar Siswa Pra Siklus, Siklus I dan Siklus II

Berdasarkan analisis data hasil belajar menunjukkan pada saat pra siklus ketuntasan belajar siswa hanya $23,08 \%$, kemudian meningkat menjadi $46,15 \%$ pada siklus I dan pada siklus II ketuntasan belajar sudah mencapai 92,31\%. Pada siklus I, ketuntasan belajar secara klasikal belum tercapai sesuai indikator keberhasilan yang ditentukan. Hasil refleksi pada saat pembelajaran siklus I menunjukkan kurangnya penguatan guru dalam pembelajaran, sehingga siswa masih kurang percaya diri ketika mengungkapkan gagasan. Guru juga kurang merata dalam memberikan bimbingan. Masih terdapat siswa yang kebingungan mengikuti tahap-tahap pembelajaran, sehingga mereka ragu dan malu untuk bertanya.

Dari hasil refleksi di Siklus I tersebut, kemudian dilakukan pengulangan pembelajaran pada Siklus II dengan beberapa perbaikan. Pembelajaran siklus I belum mencapai indikator keberhasilan sehingga diberikan tindakan pada siklus II dengan di perkuat penggunaan langkah pembelajaran Problem Based learning antara lain (1) Orientasi siswa pada masalah, (2) Mengorganisasikan siswa untuk belajar, (3) Membantu penyelidikan siswa, (4) Mengembangkan dan menyajikan hasil karya, (5) Menganalisis dan mengevaluasi proses pemecahan masalah. Ternyata menunjukkan peningkatan hasil belajar secara signifikan. Pada Siklus I, dari 13 siswa yang mengikuti evaluasi pembelajaran terdapat 6 siswa $(46,15 \%)$ tuntas atau mampu mencapai KKM $(75)$ dan 7 siswa $(53,85 \%)$ tidak tuntas atau masih berada dibawah KKM. Nilai tertinggi yang dicapai siswa adalah 85 dan nilai terendah 55 dengan nilai rata-rata kelas adalah 71.15 Sedangkan di Siklus II, dari 13 siswa yang mengikuti evaluasi pembelajaran terdapat 12 siswa (92,31\%) tuntas atau mampu mencapai KKM (75) dan hanya 1 siswa $(7,69 \%)$ yang tidak tuntas atau masih berada dibawah KKM. Nilai tertinggi yang dicapai siswa adalah 95 dan nilai terendah 70 dengan nilai rata-rata kelas 
adalah 75,75 Jadi pada siklus II hasil belajar siswa telah mencapai indikator keberhasilan yang ditentukan yang berarti melalui penerapan model Problem Based Learning dapat meningkatkan hasil belajar siswa.

Pada siklus II, hasil belajar siswa telah mencapai indikator keberhasilan yang ditentukan. Hal tersebut berarti melalui penerapan model Problem Based Learning dapat meningkatkan. Hasil penelitin ini sejalan dengan penelitian yang dilakukan Yuliana Septiana (2012). Yulianan Septiaa dalam penelitiannya yang berjudul Pendekatan Problem Based Learning (PBL) untuk meningkatkan pemahaman konsep siswa kelas IV SD Negeri Cigugur Girang Kecamatan Parongpong Kabupaten Bandung Barat menyimpulkan bahwa model Problem Based Learning dapat menciptakan situasi belajar yang interaktif antara guru dengan siswa, dan antara siswa dengan siswa serta dapat meningkatkan pemahaman konsep siswa, terbukti dengan meningkatnya nilai presentase pada setiap siklus.

Hasil penelitian ini juga relevan dengan penelitian yang dilakukan oleh Rhendi Pasaribu (2015). Penelitian yang dilakukan oleh Rhendi Pasaribu berjudul "Penerapan Model Problem Based Learning" untuk Meningkatkan Aktivitas dan Hasil Belajar Siswa Kelas XI SMA Negeri 1 Semarang Tahun Pelajaran 2015/2016" membuktikan bahwa setelah diterapkan model Problem Based Learning dalam pembelajaran, maka aktivita dan hasil belajar siswa menjadi meningkat.

Penelitian yang dilakukan oleh Dede Suryani (2016) juga memperkuat hasil penelitian ini. Penelitian yang dilakukan oleh Dede Suryani berjudul "Penerapan Problem Based Learning untuk Meningkatkan Pemahaman Hasil Belajar Siswa Kels IV SDN Leuwiliang Sumedang pada Subtema Kebersamaan dalam Keberagaman membuktikan bahwa penerapan model Problem Based Learning dalam pembelajaran mampu meningkatkan pemahaman hasil belajar siswa pada materi terkait.

\section{Simpulan dan Saran}

Berdasarkan penelitian yang telah dilakukan terkait penerapan model pembelajaran Problem Based Learning untuk meningkatkan hasil belajar Subtema Keberagaman Budaya Bangsaku di Negeriku pada siswa kelas 4 SD Negeri Purwosari Temanggung, maka dapat disimpulkan bahwa model pembelajaran Problem Based Learning telah dapat meningkatkan hasil belajar siswa. Analisis data hasil belajar menunjukkan pada prasiklus ketuntasan belajar siswa hanya $23,08 \%$, meningkat menjadi $46,15 \%$ pada siklus I dan pada siklus II ketuntasan belajar sudah tercapai sebesar 92,31\%. (1) Model pembelajaran Problem Based Learning ini dapat dijadikan sebagai salah satu alternatif guru dalam membelajarkan tema Indahnya Kebersamaan pada siswa kelas IV SD untuk meningkatkan hasil belajarnya, (2) Tindakan yang dilakukan dalam menerapkan model pembelajaran Problem Based Learning ini diharapkan dapat dijadikan umpan balik bagi siswa untuk lebih meningkatkan hasil belajar mereka melalui kemampuan memecahkan masalah, (3) Penelitian ini diharapkan dapat menjadi refleksi dan evaluasi untuk keperluan penelitian selanjutnya yang relevan.

\section{Daftar Rujukan}

Giarti, Sri. 2014. Peningkatan Keterampilan Proses Pemecahan Masalah dan Hasil Belajar Matematika Menggunakan Model PBL Terintegrasi Penilaian Autentik pada Siswa Kelas VI SDN 2 Bengle Wonosegoro. Scholaria. 4 (3), 13-27.

Hajar, Nasaul Azmy, A.Y Djoko Darmono, A,B,C. (2015). Pengaruh Model pembelajaran Problem Based Learning(pbl) Untuk Meningkatkan Hasil Belajar Siswa x-3 Pada Mata Pelajaran Sosiologi sma Negreri Kebakkramat Tahun Pelajaran 2015-2016 Jurnal IImiah Pend.Sos Ant, 7 (2) 
Henny Dewi Koeswati dkk. (2018). Model Problem Based Learning (PBL) Berbasis Media Interaktif Untuk Meningkatkan Keterampilan Berpikir Kritis dan Hasil Belajar Pada Sub Tema Lingkungan Tempat Tinggalku Kelas 4 SD. Temanggung: UKSW.

Komalasari, K. (2010). Pembelajaran Kontekstual Konsep dan Aplikasi. Bandung: PT Refika Aditama.

Pasaribu, R. (2015). Penerapan Model Problem Based Learning" untuk Meningkatkan Aktivitas dan Hasil Belajar Peserta didik Kelas XI SMA Negeri 1 Semarang Tahun Pelajaran 2015/2016. Semarang: UNNES.

Purwanto. (2010). Evaluasi Hasil Belajar. Yogyakarta: Pustaka Belajar.

Rusman. (2017). Belajar \& Pembelajaran "Berorientasi Standar Proses Pendidikan". Jakarta: Kencana.

Sagala, Syaiful., 2010. supervisi Pembelajaran Dalam Profesi Pendidikan Bandung: Alfabeta. Hal 258

Septiana, Y. (2012). Pendekatan Problem Based Learning (PBL) Untuk Meningkatkan Pemahaman Konsep Peserta didik Kelas IV SD Negeri Cigugur Girang Kecamatan Parongpong Kabupaten Bandung Barat.

Sudjana, Nana. (2010). Dasar-dasar Proses Belajar Mengajar. Bandung: Sinar Baru Algesindo.

Suryani, D. (2016). Penerapan Problem Based learning untuk Meningkatkan Pemahaman Hasil Belajar Peserta didik Kels IV SDN Leuwiliang Sumedang pada Subtema Kebersamaan dalam Keberagaman. Sumedang: Unpas.

Suwandi, Y. (2015). Peningkatan Hasil Belajar IPA Tentang Ekosistem Melalui Metode Problem Based Learning Pada Siswa Kelas V Sekolah Dasar Kabupaten Tana Tidung. Jurnal Pendidikan Dasar Volume 6 Edisis 1 mei 2015, 93 - 102.

Syafriana, D. (2016). Penerapan Model Problem Based Learning (Pbl) Dalam Pendekatan Saintifik Untuk Meningkatkan Hasil. Jurnal Inovasi Pendidikan Dan Pembelajaran Sekolah Dasar, 30 - 43.

Wahyudi, M. D. (2013). Meningkatkan Hasil Belajar Konsep Sifat - Sifat Cahaya Menggunakan Model Pembelajaran Problem Based Learning (PBL) Dan Word Square Pada Siswa Kelas V SDN Pemurus Dalam 7 Banjarmasin. Jurnal Paradigma Volume 8 Nomor 1 Januari - Juni 2013, 1 -7. 